\title{
Peran Keteladanan Pemimpin dalam Keluarga Berdasarkan Efesus 5: 21-6:4
}

\author{
Joko Santoso \\ Sekolah Tinggi Theologia Nazarene Indonesia, Yogyakarta \\ ps.johsantoso@gmail.com \\ Sukirdi \\ Sekolah Tinggi Theologia Nazarene Indonesia, Yogyakarta \\ kirdiyohanes@yahoo.co.id
}

\begin{abstract}
God created a man for a purpose. Humans can achieve goals because God gives knowledge and abilities about these goals. That is how God establishes a leader in the family. God equips one's needs to be able to lead a family properly, appropriately and successfully. Leadership in the family is referred to as the head of the family, usually led by a man. Man in the family stands as husband to wife and as a father to children. A man carries out this leadership goal as leaders in providing the right, correct and good role models. It is not easy for family members to face a pandemic situation that limits all activities in living every day, so it impacts relationships and interactions. It can even lead to disputes and conflicts between family members. Researchers used qualitative methods with an exposition, interview and literature approach. The results and discussion found the basics of exemplary leaders in the family and then applied them in everyday life.
\end{abstract}

Keywords: Man; Leadership; Application; family

\begin{abstract}
Abstrak
Manusia diciptakan oleh Tuhan untuk suatu tujuan. Tujuan dapat dicapai oleh manusia, karena Tuhan memberi pengetahuan dan kemampuan tentang tujuan tersebut. Begitulah Tuhan menetapkan seorang pemimpin dalam keluarga. Tuhan memperlengkapi kebutuhan seseorang untuk dapat memimpin keluarga dengan benar, tepat dan berhasil. Kepemimpinan dalam keluarga disebut sebagai kepala keluarga, yang biasanya dipimpin oleh seorang pria. Pria dalam keluarga berdiri sebagai suami terhadap isteri dan sebagai ayah terhadap anak-anak. Tujuan kepemimpinan tersebut dilakukan oleh pria sebagai pemimpin agar dapat memberi keteladanan yang tepat, benar dan baik. Sebab tidak mudah anggota keluarga menghadapi situasi pandemic yang membatasi seluruh kegiatan dalam menjalani kehidupan setiap hari, sehingga berdampak pada relasi dan interaksi, bahkan dapat menimbulkan perselisihan dan pertentangan antar anggota keluarga. Peneliti menggunakan metode kualitatif dengan pendekatan eksposisi, wawancara dan literatur. Hasil dan pembahasan ditemukan dasar-dasar keteladanan pemimpin dalam keluarga, dan selanjutnya diterapkan dalam kehidupan seharihari.
\end{abstract}

Kata Kunci: Pria; Kepemimpinan; Penerapan; Keluarga 


\section{PENDAHULUAN}

Alkitab menceritakan tentang tokoh-tokoh yang tidak berhasil memimpin di dalam keluarganya. Bukan hanya orang biasa, tetapi orang-orang yang dipakai Tuhan; baik sebagai Raja, Imam dan Hakim. Seharusnya sebagai pemimpin, baik di dalam keluarga maupun tugas tanggungjawabnya di tengah-tengah masyarakat mencerminkan hidup yang saleh, takut akan Tuhan. Sejarah mencatat bagaimana para tokoh yang seharusnya menjadi panutan dan teladan, tetapi justru sebaliknya. Ada tokoh-tokoh Alkitab yang memperlihatkan kebobrokan dan kegagalan dalam membina keluarga, meski ada yang berhasil dalam kepemimpinan dalam pemerintahan. Contoh nyata yaitu Imam Eli dikisahkan dalam 1 Samuel 2:11-26¹ , Raja Daud yang juga dikisahkan dalam 2 Samuel 13. Hal ini, membuktikan, bahwa berhasil menjadi pemimpin dalam pemerintahan atau keagamaan bukan berarti secara otomatis berhasil dalam memimpin keluarga. Kenyataan ini berbicara, bahwa di sepanjang sejarah manusia tidak sedikit keluarga yang gagal dan tidak berhasil dalam membangun, mempertahankan dan mencapai tujuan membina keluarga.

\footnotetext{
${ }^{1}$ Yushak Soesilo, “, Keluarga Eli Dalam 1 Samuel 2:11-36: Suatu Evaluasi Pendidikan Kristen Dalam Keluarga Hamba Tuhan, , Vol 3, No,5 2014," Jurnal Antusias Vol 3, No (2014): 8.
}

Bukan saja terjadi pada masa lalu dengan segala macam persoalannya, tetapi juga di zaman sekarang ini. Tidak luput juga terjadi pada keluarga-keluarga Kristen dewasa ini diperhadapkan dengan pola hidup new normal. New normal bukan saja hanya bicara bagaimana hidup sehat, teratur dan disiplin dalam menjalani kehidupan, tetapi juga bagaimana harus berhadapan dengan virus covid-19 yang tidak kelihatan dan begitu terjangkit virus tersebut, manusia akan mengalami kondisi yang sangat memprihatinkan, karena tidak sedikit yang meninggal dunia karenanya. ${ }^{2}$ Disatu sisi, semua kegiatan dan aktifitas harus tetap dilaksanakan, tetapi disatu sisi harus dapat menjaga diri sedemikian ketat dengan protokol kesehatan. Polemik dalam rumah tangga semakin terasa dinamikanya. Sebagai kepala keluarga harus bekerja meski tidak sedikit yang mengalami pemutusan hubungan kerja (PHK) atau harus berusaha untuk tetap dapat memenuhi kebutuhan keluarga. Sementara itu juga harus secara bijak mengatur dan mengelola keluarga dengan berbagai cara atau pola dan strategi demi terciptanya suasana dan atmosfir yang aman, tenang dan terkendali. Sebab dengan adanya pola hidup yang baru,

\footnotetext{
${ }^{2}$ Nunung Nurwati2 Salma Matla Ilpaj1, "Analisis Pengaruh Tingkat Kematian Akibat Covid-19 Terhadap Kesehatan Mental Masyarakat Di Indonesia," Jurnal Pekerja Sosial Vol,3 No,1 (2020).
} 
banyak berpengaruh dengan relasi dan interaksi seluruh anggota keluarga. Akibat yang disebabkan oleh pandemi covid-19 tersebut sangat hebat, karena menyentuh semua lapisan masyarakat dan juga terhadap pola kehidupan keluarga yang mau atau tidak mau harus membentuk pola dan strategi dalam menghadapi yang di new normal. $^{3}$

Kenyataan di zaman sekarang ini masih banyak keluarga-keluarga yang tidak menunjukkan hidup dalam keteraturan dan mencerminkan hidup saleh. Hal ini dapat ditemukan dimasa pandemic covid 19, banyak masyarakat yang tidak mematuhi peraturan pemerintah, agar taat pada protocol kesehatan. Bisnis com melangsing berita tentang ${ }^{4}$ Satgas Covid-19 mencatat jumlah orang yang ditegur karena melanggar protokol kesehatan pada tahun baru mencapai 253.216 orang. Jumlah itu naik 176,3 persen dari pekan sebelumnya yang hanya 91.659 orang. Buktinya dapat dilihat dari tidak menggunakan masker, tidak jaga jarak, dan tidak mencuci tangan. ketika menghadiri pertemuan, hajatan ataupun pertemuan-pertemuan lainnya. ${ }^{5}$

\footnotetext{
${ }^{3}$ Albet Saragih and Johanes Waldes Hasugian, "Model Asuhan Keluarga Kristen Di Masa Pandemi Covid-19," JURNAL TERUNA BHAKTI 3, no. 1 (2020): 1-11.

4"Https://Kabar24.Bisnis.Com/Read/2021 0106/15/1339403/Selama-Tahun-BaruPelanggaran-Protokol-Kesehatan-Naik-1763Persen.," n.d.

${ }^{5}$ Simon Simon and Lindin Anderson,
}

Bahkan ketegangan-ketegangan pun bisa terjadi sewaktu-waktu, ketika situasi yang terjadi di sana-sini mencekam oleh gejolak yang disebabkan banyaknya berita yang menyatakan bahwa virus sudah merajalela dan memakan banyak korban jiwa dan meninggal. Belum adanya informasi dari pemerintah yang harus ditaati demi keselamatan bersama.

Kondisi seperti ini keluarga membutuhkan kepemimpinan dalam bersikap dan berperilaku, melalui pembentukan moral dan agama. Sehingga seluruh anggota keluarga memiliki kesadaran diri membangun hidup dalam keteraturan. Sebagai pemimpin keluarga tidak hanya memberi pendidikan tetapi juga harus berkomitmen dan penuh dedikasi memberikan keteladanan demi tegaknya hidup teratur. Dan dalam kepemimpinan yang baik, bijak dan tepat dapat tetap menjaga keberlangsungan perjalanan keluarga dalam mencapai harapan dan citacita.

Tuhan telah menetapkan keluarga sebagai kesatuan dasar sebuah masyarakat. ${ }^{6}$ Setiap keluarga harus memiliki seorang

\footnotetext{
"Covid-19 Memudarkan Rasa Kemanusiaan Terhadap Sesama Dan Implikasinya Bagi Orang Percaya," Sabda: Jurnal Teologi Kristen 1, no. 2 (2020): 85-104.

${ }^{6}$ Hardi Budiyana, "Perspektif Alkitab Terhadap Keluarga Kristen," REGULA FIDEI: Jurnal Pendidikan Agama Kristen 3, no. 2 (2018): 137145.
} 
pemimpin. Kepemimpinan dalam rumah tangga itu sangat penting, karena menentukan keberhasilan dalam keluarga untuk mencapai tujuan dan kehendak tuhan dalam membangun kehidupan berkeluarga. Itulah sebabnya, seorang suami sebagai pemimpin menjadi kepala keluarga harus memiliki pemahaman yang benar dan jelas sebagaimana Alkitab ajarkan. Yaitu menjadi pemimpin yang berkarakter kristus dan berkualitas unggul. Sehingga dalam pelaksanaan peran dan tanggung-jawabnya tidak menyimpang dan berhasil mencapai tujuan seperti yang telah ditetapkan Tuhan. Pada akhirnya, keluarga Kristen yang mempraktekkan keteladanan sesuai dengan Alkitab. Sehingga keluarga dapat memancarkan kemuliaan Tuhan dan menjadi kesaksian bagi lingkungan dan masyarakat pada umumnya. ${ }^{7}$ Salah satu teks yang dapat dijadikan dasar kepemimpinan dalam keluarga adalah Efesus 5:22-6:4. Sehingga dengan memiliki landasan dasar tersebut, keluarga dapat menjalani kehidupan yang teratur, disiplin dan taat pada hukum. Pada akhirnya, kepala keluarga dapat mengajarkan keteladanan

\footnotetext{
${ }^{7}$ ARNI PALEMBANGAN, "Penginjilan Dalam Keluarga Kristen” (2020).

${ }^{8}$ Joko Santoso, "Penerapan Pondasi Keluarga Bagi Generasi Penerus," Jurnal Ilmiah Religiosity Entity Humanity (JIREH) 2, no. 2 (2020): 170-183.

${ }^{9}$ M.Hum Dr. Farida Nugrahani, Metode Penelitian Kualitatif (Sukarakarta: univetbantara, 2014). hal 19
}

dalam keluarga dan menunjukkan tanggung jawab atas keluarga yang dipercayakan Tuhan kepadanya. ${ }^{8}$

\section{METODE PENELITIAN}

Penelitian ini menggunakan metode kualitatif yang bertujuan untuk menangkap dan memahami makna dari suatu konteks dalam kondisi apa adanya (natural setting) ${ }^{9}$. Dengan pendekatan eksposisi ${ }^{10}$ yang berarti mengungkapkan atau penyingkapan secara formal tentang suatu kenyataan ${ }^{11}$ terhadap Surat efesus 5:22-6:4 guna menganalisis kata demi kata pada nats tersebut yang diperluas dengan tafsiran dan gambaran untuk menemukan dasar-dasar kepemimpinan untuk dipraktekkan di dalam keluarga. Selanjutnya dilakukan wawancara terhadap partisipan guna mendapatkan informasi apa yang sebenarnya terjadi di lapangan. Kemudian dilakukan penelusuran dan kajian dari bacaan; baik bahan bacaan buku atau artikel jurnal ilmiah guna mencari data-data literatur mengenai kondisi dimasa kini di era New Normal. ${ }^{12}$

\footnotetext{
${ }^{10}$ Sonny Eli Zaluchu, "Strategi Penelitian Kualitatif Dan Kuantitatif Di Dalam Penelitian Agama," Evangelikal, Jurnal Teologi Injili dan Pembinaan Warga Jemaat Volume 4, (n.d.): 34.

${ }^{11}$ Tim Penyusun, KBBI Edisi Keempat (Jakarta: Gramedia, 2013). 9

${ }^{12}$.M.Sc Dr.J.R. Raco, ME, Metode Penelitian Kualitatif(Jakarta: Gramedia, 2010). hal 72
} 
HASIL DAN PEMBAHASAN

\section{Eksposisi terhadap surat Efesus}

\section{$5: 22-6: 4$}

Ketundukan (Efesus 5:22)

Dalam terjemahan Lembaga Alkitab Indonesia kata "tunduklah" adalah kata kerja dalam bentuk perintah, secara eksplisit memang tidak tampak dalam teks King James Version (KJV), karena menggunakan kata "serahkan" bukan "tunduklah", Bruce dalam bukunya textual comentary $^{13}$ mengatakan; bahwa beberapa saksi awal seperti bapak gereja; Clement, Origen, dan Jerome Theodore memulai kalimat baru ini tanpa menggunakan kata kerja, maka dibutuhkan penekanan dari bagian berikutnya yaitu kata hupotasso di bagian bawah. Sedangkan kata "idiois" adalah merupakan kata sifat yang menjelaskan kepemilikan pribadi. Jadi setiap isteri diperintahkan untuk hupotasso atau tunduk kepada suami mereka masingmasing. Hal ini berarti bahwa Paulus menegaskan kepada para istri, agar memiliki sikap tunduk yang benar atau kualitas ketundukan yang harus dilakukan terhadap suami, yaitu sikap tunduk seperti

\footnotetext{
${ }^{13}$ Bruce M. Metzger, A Textual Comenntary on The Greek New Testament (New York: American Bible Society, 1865).

14“"Thayer's Greek Lexicon, STRONGS NT 2776," n.d.
}

kepada Kristus. Penulis sependapat dengan hal ini, sebab dalam kristus hupotasso yang bermakna "ketundukan" merupakan respon isteri atas kasih dari sang suaminya yang digambarkan seperti Kristus. Jadi respon ketundukan isteri, lahir dari kasih yang harus dimiliki dan suami kepada istrinya. Seperti kasih Kristus yang besar kepada jemaat, demikianlah kasih suami kepada istri, sehingga isteri dituntut untuk tunduk dengan kasih kepada suami.

\section{Otoritas (Efesus 5:23-24)}

Kata kepala dalam teks Yunani $\kappa \varepsilon \varphi \alpha \lambda \eta$ atau kephale. Secara hafiah berarti "head or leader". ${ }^{14}$ Berdasarkan makna harfiah dari kata kephale memang lebih merujuk pada otoritas, namun otoritas yang dimaksudkan bukan masalah superioritas terhadap inferioritas tetapi otoritas yang berfungsi penanggungjawab, pelindung, dan pegang peranan yang penting ${ }^{15}$

Jadi ketundukan isteri kepada suami lahir sebagai respon peran suami sebagai kepala yang bertanggungjawab penuh dalam keluarga, melindungi keluarga, dan menjadi central penting dalam keluarga. Makna tersebut di atas sesuatu dengan peran Kristus terhadap jemaatNya.

\footnotetext{
${ }^{15}$ Hendro Hariyanto Siburian, "Studi Eksposisi Tanggung Jawab Suami Istri Menurut Efesus 5: 22-33 Dan Aplikasinya Bagi Keluarga Kristen Masa Kini” (2020).
} 
Demikian Paulus membandingkan keotoritasan seorang suami terhadap seorang isteri, dengan sebagaimana halnya otoritas Kristus kepada jemaat sebagai suatu hal yang sama. Perbandingan ini menghasilkan dua kesan kuat yang secara deklaratif disampaikan Paulus kepada jemaat, yaitu: Pertama, Allah telah memberikan otoritas kepada suami atas isterinya. Dan kedua, kualitas atau esensi dari otoritas itu ditemukan di dalam karya Kristus sebagai kepala Gereja terhadap jemaatNya.

Paulus melanjutkan penjelasannya dalam ayat 24 , tentang mengapa suami adalah kepala atas isteri. Paulus mengatakan "karena itu sebagaimana jemaat tunduk kepada Kristus", kata "tunduk" menggunakan kata yunani

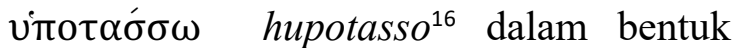
tenses present passive indikatif dari kata

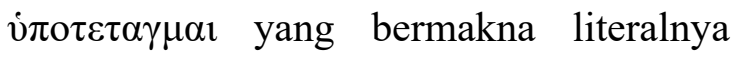
artinya 'tunduk', taat, berada di bawah otoritas, mengambil tempat bagian bawah. Jadi ketundukan jemaat kepada Allah bukan didasarkan pemaksaan, melainkan mengandung unsur penyerahan diri secara sukarela dari jemaat untuk ditundukkan dan mematuhi Allah sebagai kepala Gereja. Suami dan isteri perlu memahami sifat sukarela yang dimaksudkan jangan sampai keliru.

Jadi ketundukan secara sukarela harus dipahami sebagai respon positif, yang dengan rela bersedia dipimpin, diarahkan untuk pencapaian yang lebih baik. Ketundukan isteri kepada suami, memiliki kualitas atau esensi motivasi yang sama seperti jemaat tunduk kepada Kristus, jadi suami sebagai kepala menunjukkan keteladanan ketundukkan kepada isteri. Sehingga dalam sikap tunduk terdapat sikap saling membangun persekutuan yang tulus, ikhlas dan penuh syukur yang mencerminkan hubungan Kristus dan jemaat sebagai teladan yang sejati.

\section{Kasih ( Efesus 5:25)}

Di dalam ayat selanjutnya dapat dilihat hubungan timbal balik, yaitu sikap atau tugas suami kepada isterinya. Dalam ayat 25 dijelaskan : "Hai suami, kasihilah isterimu sebagaimana Kristus telah mengasihi jemaat dan telah menyerahkan diriNya baginya",. Paulus menggunakan kata perintah "kasihilah" untuk menyampaikan pesannya kepada para suami. Kata ' $\alpha \gamma \alpha \pi \alpha ́ \omega ’$ merupakan kata kerja present aktif imperatif, yang berarti bentuk perintah dengan tenses present aktif, dilakukan secara terus menerus dan belum selesai. ${ }^{17}$ Inilah kebenaran sejati di dalam 
terang Kristus, sebab isteri bukan merupakan pihak inferior dari superiornya para suami, melainkan para suami dituntut untuk mencintai isteri dengan kesetiaan. Prinsip dari perintah untuk mengasihi isteri dilandasi Paulus dengan dasar "sebagaimana Kristus mengasihi jemaat". Pada bagian ini kata "mengasihi" adalah dalam bentuk tenses aorist aktif indikatif dari kata dasar agapao yang secara harafiah diterjemahkan dalam bahasa Inggris adalah "To love, wish well to, take pleasure in, longfor; denotes the love of reason, esteem. Perhaps from agan; to love" 18 yang berarti menyatakan cinta atau menunjukkan cinta dengan kepribadian yang teguh. Sedangkan bentuk tenses aorist menjelaskan suatu kegiatan di masa lalu yang telah selesai dikerjakan, maka penggunaan kata "agapesen" dalam bentuk aorist menjelaskan karya kasih Yesus yang telah selesai dikerjakan atas umatNya, yaitu karya penyelamatan. Paulus menasehati para suami untuk mengasihi isteri dengan kualitas kasih Yesus kristus yang rela meninggalkan singgasanaNya yang mulia, mengosongkan diriNya dan mengambil rupa seorang hamba, serta mati di kayu salib seperti yang tertulis dalam kitab Filipi 2:6-8. Jadi konsep mengasihi yang harus mewujudkan oleh suami kepada isterinya

${ }^{18}$ Strong's Concordance 25. adalah kasih yang rela "menyerahkan dirinya" kepada isterinya, seperti Kristus yang telah menyerahkan diriNya bagi jemaat.

Sedangkan ayat 26 menggunakan kata $\dot{\alpha} \gamma \imath \dot{\alpha} \zeta \omega$ dalam Bahasa Inggris berbunyi: I make holy, treat as holy, set apart as holy, sanctify, hallow, purify""19 yang berarti menguduskan, menjadikan suci, Tindakan yang menyucikan ini menjelaskan tentang tujuan dari pengorbanan tersebut, yaitu: "untuk menguduskannya, sesudah Ia menyucikannya dengan memandikannya dengan air dan firman". Penggunaan bentuk aorist aktif subjunctive pada kata ini menjelaskan bahwa kegiatan kata kerja utama. Karena kata menguduskan memiliki tenses yang sepadan dengan kata kerja 'penyerahan' di dalam ayat 25, maka makna tindakan penyerahan diri Kristus adalah tindakan pengudusan umat-Nya, dan kedua kata kerja ini dalam tenses aorist; kegiatan sudah sempurna dan telah selesai. Hal penting teks ini menegaskan kepada para suami, istri dan anak, bahwa melalui pengorbanan Kristus, umat-Nya telah dikuduskan yaitu ditetapkan sebagai yang suci bagi Allah, dan menjadi dedikasi untuk melayani dan setia kepada Allah. Jadi Allah terlebih dahulu menyucikan jemaat-Nya, 
Dan Allah menyucikan jemaat-Nya dengan 'air dan firman'. Dalam teks Yunani kata air diterjemahkan 'the bath of water' atau air pemandian'. Thayer's Greek Lexicon ${ }^{20}$ menjelaskan bahwa frasa ini ini merujuk pada 'air baptisan.

Dalam ayat 27 dijelaskan tujuan dari pengorbanan, pengudusan, dan pembersihan yang dilakukan Kristus atas jemaat, yaitu "supaya Ia menempatkan jemaat dihadapan diri-Nya dengan cemerlang tanpa cacat atau kerut tetapi supaya jemaat kudus dan tidak bercela'. Paulus menjelaskan bahwa jemaat ditempatkan dihadapan Kristus dalam keadaan yang tak bercela. ${ }^{21}$ Yang dimaksud kata 'cemerlang' dari teks endoxon yang diterjemahkan 'honored, distinguished, of spirittual exellence glorious, wonderful' artinya 'terhormat, berbeda, jemaat unggul rohani, dan indah'. Sedangkan kata 'tanpa

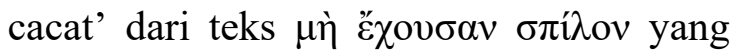
secara harafiah diterjemahkan 'tidak memiliki ketidak-sempurnaan moral'. Kata kerja "echousan" dalam bentuk tenses present aktif, artinya tindakan aktif secara terus menerus untuk tidaak memiliki sikap moral yang bercacat atau salah ${ }^{22}$.

Jadi ayat 27 sangat jelas dilihat kasih Kristus yang besar atas jemaat-Nya, karena

${ }^{20}$ Thayer's Greek Lexicon 37

${ }^{21}$ J.L. Ch. Abineno, Tafsiran Efesus (Jakarta: BPK Gunung Mulia, 1998).191 secara aktif Ia bertindak menyerahkan diriNya agar umat-Nya mengalami perubahan status atau dilayakkan menghadap Allah. Kristus ingin jemaat-Nya menjadi terhormat, indah, dan secara terus-menerus memiliki kesempurnaan moral. Kristus memiliki tujuan menjadikan jemaat-Nya memiliki superioritas kualitas moral, sifat dasar yang ilahi, tanpa kesalahan, dan sempurna.

Setelah menjelaskan besarnya kasih Allah dalam ayat-ayat sebelumnya bagi jemaat, di dalam ayat 28 Paulus kembali menasehati suami untuk "mengasihi isteri sama seperti tubuhnya sendiri”. Kata awal yang digunakan paulus untuk mengawali kalimatnya adalah 'demikianlah' dari kata ou menunjukkan kepada hubungan antara Kristus dan jemaat; sebagaimana Kristus telah mengasihi jemaat dan telah menyerahkan diriNya untuk menguduskan jemaat, ' demikianlah' juga suami harus mengasihi isterinya. Kata ovfei, lousin diterjemahkan "harus" berarti wajib, mengasihi isteri sesuatu keharusan atau suatu kewajiban. ${ }^{23}$

Paulus menjelaskan bahwa mengasihi isteri seperti mengasihi 'tubuhnya' sendiri. Kata 'tubuh' dari kata $\sigma \tilde{\omega} \mu \alpha$ dalam Bahasa Inggris diterjemahkan 'body' yang artinya : 
'tubuh, tubuh hidup, tubuh fisik'. ${ }^{24}$ Jadi 'tubuh' yang Paulus maksudkan adalah sungguh-sungguh daging fisik manusia. Dengan demikian pernikahan berarti 'menyatukan dua tubuh yang berbeda'. Kemudian Paulus juga menambahkan, bahwa arti "mengasihi isteri adalah mengasihi diri sendiri", karena isteri adalah tubuhnya sendiri atau bagian yang telah disatukan kepada tubuhnya sendiri.

Paulus juga memperjelas eksistensi isteri yang adalah bagian tubuh fisik dari suami dalam ayat 29 "tidak pernah orang membenci tubuhnya sendiri, tetapi mengasuhnya dan merawatinya, sama seperti Kristus kepada jemaat”. Pada ayat ini Paulus dengan tegas mengatakan bahwa isteri adalah tubuh fisik suami itu sendiri, sebab itu suami tidak dibenarkan "membenci isterinya, tetapi harus "mengasuhnya" dan "merawatinya". Kata membenci dari kata dalam bentuk aorist aktif indikatif dari kata diterjemahkan : love less, despise, disregard, be indifferent to' artinya: 'kurang cinta, menghina, mengabaikan, dan tidak memperdulikan. ${ }^{25}$ Kata 'mengasuh' dari kata dalam bentuk present aktif indikatif dari kata adalah keluar atau mengintensifkan, adalah menyehatkan atau memelihara.

\footnotetext{
4983

${ }^{24}$ Thayer's Greek Lexicon STRONGS NT

${ }^{25}$ Alford Henry, The New Testament For
}

Jadi, Kristus tidak pernah berkekurangan dalam mencintai umat-Nya, menyediakan seluruh kebutuhan jemaatNya, karena bagi Kristus jemaat adalah tubuh-Nya sendiri. Sebab itu dalam ayat 30 dikatakan bahwa, jemaat adalah anggota tubuh-Nya, artinya bagian dari tubuh fisikNya; dan merupakan gambaran kesatuan Kristus dengan jemaat. Jadi seperti yang telah Kristus lakukan kepada jemaat-Nya, demikianlah suami harus lakukan kepada isterinya, yaitu mengasihi isterinya yang adalah tubuh fisiknya sendiri.

\section{Tujuan (Efesus 5:31-33)}

Ayat 31 berbunyi : Sebab itu laki-laki akan meninggalkan ayahnya dan ibunya dan bersatu dengan isterinya, sehingga keduanya itu menjadi satu daging”. Yang dimaksud dengan kata 'bersatu' dari kata $\pi \rho о \sigma \kappa о \lambda \lambda \eta \theta \eta \dot{\sigma \varepsilon \tau \alpha \imath ~ d a l a m ~ b e n t u k ~ f u t u r e ~}$ passive indikatif dari kata dasar $\pi \rho о \sigma \kappa о \lambda \lambda \alpha ́ \omega, \quad$ yang diterjemahkan: menggabungkan diri secara resmi, bersatu dengan, menempel, menjadi abdi yang setia”. Dalam bentuk future passive indikatif, kata proskollao bermakna 'akan digabungkan secara erat, akan disatukan dengan, akan ditempel, akan dikhususkan menjadi yang setia'26.

\section{English Readers Ephesians commentary (PRECEP AUSTIN) \\ ${ }^{26}$ Strong's Concordance, 4347}


Jadi laki-laki akan meninggalkan ayah dan ibunya, kemudian dipersatukan secara erat dengan isterinya; akan dikhususkan menjadi setia dengan isterinya. Inilah yang dijelaskan Paulus dengan frasa menjadi 'satu daging'. Dalam teks ini 'daging' menggunakan kata sarka yang secara harafiah diterjemahkan: manusia dengan tubuh secara fisik dan darah, yang berhubungan dengan lingkup duniawi dari eksistensi manusia.

Dalam ayat 32 Paulus menambahkan keterangan mengenai penjelasannya di ayat 31, ia mengatakan bahwa rahasia "kesatuan" ini adalah rahasia yang besar. Kemudian hubungan suami isteri mengerucut pada hubungan Kristus dan jemaat, sebagai suatu hubungan dalam penjelasan ayat 32" Rahasia ini besar, tetapi yang aku maksudkan ialah hubungan Kristus dan jemaat." Yang dimaksud dengan 'rahasia' dari kata musthrion adalah rahasia dari arti atau rahasia kasih Kristus dengan jemaat. ${ }^{27}$ Dan ternyata makna bersatunya laki-laki dan isterinya menjadi satu keinginan dan kebutuhan, merupakan gambaran hubungan Kristus dan jemaatNya.

Dan dibagian akhir dari konteks nasehat hubungan suami isteri ini, Paulus menegaskan kesimpulan dalam ayat 33

27.J.L.Ch. Abineno, Tafsiran Efesus, 195

${ }^{28}$ Strong's Concordance 25 "kasihilah isterimu seperti dirimu sendiri dan isteri hendaklah menghormati suaminya" sebagai rangkuman dari sikap yang telah diterangkan diatas. Kata kasihilah menggunakan kata avgapatow bentuk present aktif imperative. ${ }^{28}$ Kata 'agapato' dalam bentuk perintah dengan tense present, artinya tindakan kesetiaan, memandang tinggi/hormat, menempatkan di tempat penting dalam hati secara terus menerus dan berulang-ulang terhadap isteri, seperti mencintai diri sendiri. Sedangkan bagi isteri nasehat pentingnya adalah menghormati suaminya, kata menghormati dari kata fobhtai dalam bentuk present passive subjunctive dari kata fobew diterjemahkan: properly, to prefer, to love; for the believer, preferring to "live through Christ" reverence, have respect, fear for toward persons, yang artinya : hormat terhadap, memiliki sikap hormat terhadap, rasa takut terhadap. ${ }^{29}$

\section{Pendidikan Anak ( Efesus 6:1-3)}

Setelah pembahasan tentang hubungan suami isteri, Paulus beralih kepada hubungan orang tua dengan anakanaknya, dimana anak-anak dinasehati dalam ketaatan; ayat 1: "hai anak-anak, taatilah orang tuamu di dalam Tuhan, haruslah demikian”. Kata 'taatilah' 
menggunakan kata upakouete dalam bentuk present aktif imperative dari kata upakouw yang diterjemahkan obey, follow, be subject yang artinya: mematuhi, mengikuti, tunduk. Abineno memberikan nasehat ini kepada para isteri, namun juga kepada anak-anak dituntut untuk taat. ${ }^{30} \mathrm{Jadi}$ Hupakouo menyiratkan sikap batin yang hormat dan bertanggungjawab, sebagai wujud tindakan ketaatan. Dan ketaatan anak kepada orang tua adalah dengan mendengarkan nasehat orang tua, serta menataati-Nya. ${ }^{31}$

Selain memiliki sikap batin yang hormat dan tunduk secara terus menerus kepada orang tua, Paulus juga memberikan nasehat kepada anak-anak untuk menghormati ayah dan ibu. Paulus menegaskan nasehat ini dengan kata 'suatu perintah penting'. Dan kata yang digunakan untuk menjelaskan 'menghormati' adalah tima dalam bentuk present aktive imperative dari kata timaw yang diterjemahkan : as ascribing wort to someone honor, revere, respect' artinya : memandang layak sebagai seseorang yang hormat, menghormati, menghargai'. Dalam ayat 3 dijelaskan bahwa tindakan menghormati dilakukan agar 'panjang umur di bumi’.

\footnotetext{
${ }^{30}$ J.L. Ch. Abineno, 198

${ }^{31} \mathrm{~J}$. Vermon McGee, Thru The Bible Commantary (Pasadena: Thru The Radio Bible,
}

Kata panjang umur dari kata makrocronioj secara harafiah dapat diterjemahkan : 'waktu yang lama, jangka waktu umur yang panjang, jarak waktu yang lama, waktu yang panjang untuk sesuatu". Secara harfiah makna kata ini merujuk pada usia yang panjang, namun secara figurative teks ini bertujuan memberikan gambaran tentang berkat yang dilahirkan dari sikap hormat kepada orang tua. Namun Thayer's ${ }^{32}$ menjelaskan bahwa makna umur panjang tidak secara harfiah berarti umur yang banyak, melainkan gambaran hidup yang diberkati atau dalam kelimpahan. Sebab hidup menurutnya tidak diukur oleh kuantitas waktu, melainkan juga pada kualitas waktu selama hidup.

Kemudian Paulus juga mengatakan kepada para bapak dalam ayat ke 4 : "Dan kamu, bapa-bapa janganlah bangkitkan amarah di dalam hati anak-anakmu, tetapi didiklah mereka di dalam ajaran dan nasehat Tuhan". Paulus menjelaskan dampak bahayanya jika bapa-bapa membangkitkan amarah pada anakanaknya, yaitu: "Bapa yang memanaskan hati anak-anak-nya, sehingga mereka menjadi marah, dengan sadar atau tidak sadar memimpin mereka kepada pemberontakan melawan segala sesuatu

1981).

32 “Thayer's Greek Lexicon STRONGS NT 3118," n.d. 
yang ada hubungannya dengan bapa dan dengan itu juga kepada pemberontakan terhadap Allah sebagai Bapa."

Paulus mengajarkan agar orangtua mendidik anak dalam ajaran dan nasehat Tuhan. Mendidik yang dimaksudkan dalam arti "mengasuh" dan "merawat" anak. Jadi orang tua ditugasi untuk membina dan mendidik anak sangat bersifat luas, sangat disayangkan jika orangtua hanya menyerahkan anak-anaknya dididik saja dalam asuhan orang tua asuh, baby sister, di sekolahan, tanpa peran orang tua yang sesuai dengan Firman Tuhan.

Pada akhirnya Allah merancang dan menciptakan manusia sesuai tujuan. Untuk mencapai tujuan tersebut, Tuhan memberi kemampuan untuk berfungsi dan memberi kesanggupan untuk menjalankan tujuan tersebut. Begitulah ditetapkan Allah atas Adam dan Hawa. Allah menciptakan pria untuk berfungsi sebagai suami atas isteri dan ayah bagi anak-anaknya. Jika pria sebagai bapak tidak mengerti atau tidak mengetahui tujuan mereka yang diberikan Allah, maka masalah akan timbul baik dalam identitas diri maupun dalam hubungan mereka dimasa mendatang. ${ }^{33}$

\section{Praktek Peran Keteladanan Pemimpin}

\section{Dalam Keluarga}

\footnotetext{
${ }^{33}$ Myler Munroe, Fatherhood Prinsiple
}

Berdasarkan eksposisi Efesus 5:226:4 ditemukan lima prinsip keteladanan hidup yang harus diterapkan pria dalam kepemimpinan terhadap keluarga. Adapun lima prinsip keteladanan tersebut adalah: a).Ketundukan, menunjukkan sifat memiliki bukan menguasai b). Otoritas, menunjukkan rasa tanggung jawab terhadap keluarga bukan berkuasa atau menguasai; c). Kasih, menunjukkan kepribadian yang berkualitas dalam pengorbanan dan kesetiaan; d). Tujuan, menunjukkan kedewasaan dan kemandirian dalam kesatuan; dan e). Pendidikan, menunjukkan memberikan pengasuhan dan merawat anak.

Selanjutnya kelima keteladanan tersebut dijabarkan sebagai berikut:

\section{Ketundukan}

Sebagai seorang pemimpin dalam keluarga, suami mengormati dan menghargai ketundukan isteri sebagai miliknya yaitu tulang dari tulangnya dan daging dari dagingnya (Kej. 2:23), bukan untuk dimanfaatkan sebagai kesempatan memuaskan keinginannya, tetapi justru ketundukan isteri diakibatkan suami telah mempraktekkan ketundukannya kepada Kristus, sehingga mengimpartasikan sikap ketundukan tersebut kepada seluruh anggota keluarganya.

(Jakarta: Imanuel, 2002). 22 


\section{Otoritas}

Otoritas yang dimiliki oleh seorang pria dalam keluarga untuk menunjukkan rasa tanggung jawabnya. Bukannya memimpin secara otoriter atau menguasai, sehingga dalam perjalanan keluarga menjadi pincang bahkan menimbulkan kegaduhan atau kekacauan. Masing-masing anggota keluarga bertindak semaunya sendiri menurut otoritas yang dimiliki. Siapa yang memiliki lebih pengaruh akan bertindak sebagai penguasa dan mengendalikan keluarga seturut kehendaknya. Pria sebagai pemimpin dalam keluarga mempraktekkan otoritasnya hasil dari unsur penyerahan dirinya secara sukarela mematuhi Kristus sebagai kepala gereja. Dengan adanya sikap demikian, seluruh anggota keluargapun menyerahkan diri untuk mengikuti kepemimpinannya dengan sukarela. Anggota dengan senang hati mengikuti pola atau system yang dibangun dan diterapkan dalam keluarga.

\section{Kasih}

Hal ini tidak memberikan hak kepada pria sebagai suami terhadap isteri dan pria sebagai ayah terhadap anak-anak, secara egois mendominasi isteri dan anakanaknya. Justru Allah memanggil suami untuk melakukan tindakan mengasihi, melindungi, mencukupi dan memimpin keluarganya sebagai kepala kelaurga. Itulah sebabnya kepala berbicara tentang pria yang secara sepenuh memegang pucuk kepemimpinan dalam keluarga yang dibebankan atas dirinya. Ia harus memimpin keluarga dalam situasi apapun juga dan membawa mereka mengalami pemeliharaan dan janji-janji Tuhan.

Tujuan

Perspektif tentang rencana Tuhan Allah dalam keluarga, suami harus bersatu dan mandiri untuk mengembangkan tujuan Tuhan beranak cucu dan penuhi bumi sebagai mandate Ilahi (Kej.1:26-28). Sehingga dengan memiliki pemahaman tentang rencana Allah dengan tepat, akan dapat mengambil keputusan yang tepat seperti yang dikehendaki oleh Allah. Sebab kehendak Allah berbicara tentang tujuan yang harus dicapai oleh setiap pria dalam keluarganya. Kehendak tersebut adalah tujuan hidup.

\section{Pendidikan Anak}

Orang tua mendapat tugas mengasuh dan merawat dengan cara mendidik anakanaknya. Namun orangtua sama sekali tidak boleh melalaikan disiplin, dan jangan bertindak gegabah. Sebelum menghajar anak hendaknya orangtua sudah mengetahui dengan jelas motif yang 
mendasari tindakannya, dan menghindari "menghajar" anak pada saat ia sedang marah, juga berbahaya kalau mereka malas lalu orangtua tidak mendisiplin dan menghajar anak sesuai ajaran Tuhan.

Orang tua harus menegakkan kedisiplinan dan mengajarkan kepada anakanak dalam hal budi pekerti, moral dan agama. Banyak orang tua yang tidak memperdulikan masalah budi pekerti dan moral anaknya, dengan membiarkan anaknya menempuh jalannya sendiri. Namun terlalu otoriter, juga menghalangi anak berkarya dan mengambil keputusan sendiri, sehingga si anak tak kunjung bertumbuh dewasa. ${ }^{34}$

\section{KESIMPULAN DAN SARAN}

Kepemimpinan dalam keluarga adalah suatu tugas yang berat bagi seorang pria. Itulah sebabnya harus memiliki pemahaman yang benar, motivasi yang murni, tujuan yang jelas dan pasti. Dengan pemahaman yang dimiliki akan menjadi pendorong yang kuat, yang secara terus menerus memberi kontribusi demi tercapai tujuan dan harapan keluarga sesuai dengan kehendak Tuhan.

Itulah sebabnya pria yang menghendaki membangun rumah tangga dan memiliki keluarga, sudah seharusnya

\footnotetext{
${ }^{34}$ J.L. Ch. Abineno, Tafsiran Efesus
}

memiliki pemahaman yang benar dan menghidupinya secara terus menerus sebagai kunci menuju keberhasilan menjadi teladan dalam kepemimpinan keluarga. Sebagaimana prinsip-prinsip yang telah diajarkan sesuai dengan Surat Efesus 5:226:4, yaitu: ketundukan, otoritas, kasih, tujuan dan pendidikan anak.

\section{DAFTAR PUSTAKA}

Abineno, J.L. Ch. Tafsiran Efesus, 1998.

Bruce M. Metzger. A Textual Comenntary on The Greek New Testament. New York: American Bible Society, 1865. Budiyana, Hardi. "Perspektif Alkitab Terhadap Keluarga Kristen.” REGULA FIDEI: Jurnal Pendidikan Agama Kristen 3, no. 2 (2018): 137145.

Dr. Farida Nugrahani, M.Hum. Metode Penelitian Kualitatif. Sukarakarta: univetbantara, 2014.

Dr.J.R. Raco, ME, .M.Sc. Metode Penelitian Kualitatif. Jakarta: Gramedia, 2010.

J. Vermon McGee. Thru The Bible Commantary. Pasadena: Thru The Radio Bible, 1981.

J.L. Ch. Abineno. Tafsiran Efesus. Jakarta: BPK Gunung Mulia, 1998. 
Tafsiran Efesus. Jakarta: BPK

Gunung Mulia, 1998.

Myler Munroe. Fatherhood Prinsiple.

Jakarta: Imanuel, 2002.

PALEMBANGAN, ARNI. "Penginjilan

Dalam Keluarga Kristen” (2020).

Salma Matla Ilpaj1, Nunung Nurwati2.

“ANALISIS PENGARUH

TINGKAT KEMATIAN AKIBAT

COVID-19 TERHADAP

KESEHATAN MENTAL

MASYARAKAT DI INDONESIA.”

Jurnal Pekerja Sosial Vol,3 No,1

(2020).

Santoso, Joko. "Penerapan Pondasi

Keluarga Bagi Generasi Penerus.”

Jurnal Ilmiah Religiosity Entity

Humanity (JIREH) 2, no. 2 (2020):

170-183.

Saragih, Albet, and Johanes Waldes

Hasugian. "Model Asuhan Keluarga

Kristen Di Masa Pandemi Covid-19.”

JURNAL TERUNA BHAKTI 3, no. 1

(2020): 1-11.

Siburian, Hendro Hariyanto. "Studi

Eksposisi Tanggung Jawab Suami

Istri Menurut Efesus 5: 22-33 Dan

Aplikasinya Bagi Keluarga Kristen

Masa Kini” (2020).

Simon, Simon, and Lindin Anderson.

"Covid-19 Memudarkan Rasa

Kemanusiaan Terhadap Sesama Dan

Implikasinya Bagi Orang Percaya.”
Sabda: Jurnal Teologi Kristen 1, no. 2 (2020): 85-104.

Sonny Eli Zaluchu. "Stratetgi Penelitian

Kualitatif Dan Kuantitatif Di Dalam

Penelitian Agama." Evangelikal,

Jurnal Teologi Injili dan Pembinaan

Warga Jemaat Volume 4, (n.d.): 34.

Tim Penyusun. KBBI Edisi Keempat.

Jakarta: Gramedia, 2013.

Yushak Soesilo. “, Keluarga Eli Dalam 1

Samuel 2:11-36: Suatu Evaluasi

Pendidikan Kristen Dalam Keluarga

Hamba Tuhan, , Vol 3, No,5 2014."

Jurnal Antusias Vol 3, No (2014): 8.

"Https://Kabar24.Bisnis.Com/Read/20210

106/15/1339403/Selama-Tahun-Baru-

Pelanggaran-Protokol-Kesehatan-

Naik-1763-Persen.," n.d.

“Thayer's Greek Lexicon, STRONGS NT

2776," n.d.

“Thayer's Greek Lexicon STRONGS NT 3118," n.d.

“Thayer's Greek Lexicon STRONGS NT 5293," n.d. 
188 | SANCTUM DOMINE: Jurnal Teologi, vol. 10, no. 2 (2021) 